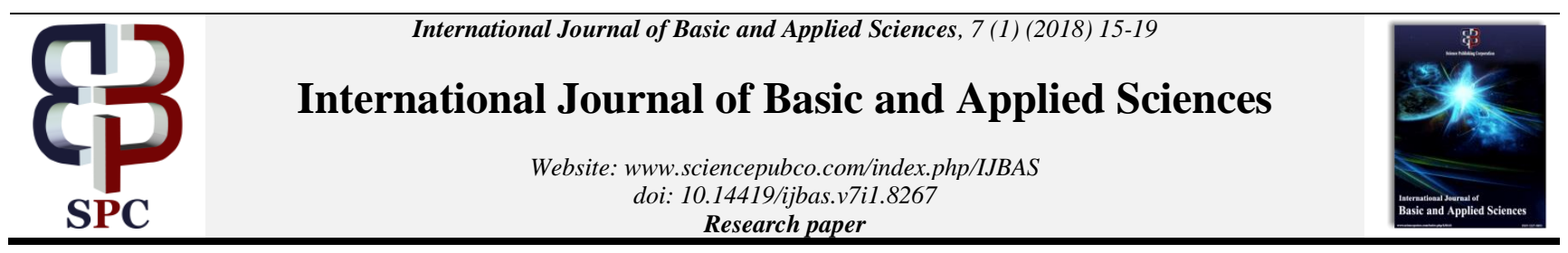

\title{
A comparative study of bulk leach extractable gold (BLEG) and fire assay methods on the Wassa deposit at Golden Star Limited, Wassa mine
}

\author{
Tawiah Christian , Manu Johnson*, Nunoo Samuel , Hayford Ebenezer \\ Department of Earth Science, University of Ghana, Legon, Ghana \\ *Corresponding authorE-mail: jmanu@ug.edu.gh
}

\begin{abstract}
Golden Star Resources Limited conducts Bulk Leach Extractable Gold (BLEG) and Fire Assay methods on samples from its exploration program. Additionally, for mining control and as part of the sampling and analytical protocol, residues of samples whose assay values are greater than $10 \mathrm{~g} / \mathrm{t}$ are subjected to fire assay to determine the quantity of gold. However, there is gold retained in the tails or residue after leaching and to verify the suitability and efficiency of the analytical method, drill samples (RC and DD) with control samples were analysed using BLEG method based on the accelerated cyanide leach extraction and Fire Assay method on the tails.

Percentages of the prepared samples were subjected to BLEG orientation study to investigate the leachability and efficiency of the BLEG method on the ore samples. Fire Assay analysis was also carried out on the selected tailing samples to find out the assay reproducibility of the samples. The analytical analyses carried out on the samples revealed that the ore samples were leachable with gold recovery levels ranging between $96 \%$ and $100 \%$ when there is total pulverization of samples to make BLEG method possible and that this procedure is also cheaper than the conventional Fire Assay.
\end{abstract}

Keywords: Birimian; BLEG; Fire Assay; Gold Recovery; Tailings.

\section{Introduction}

Type or mineralogy of a sample, presence or absence of coarse gold and other elements which are required to be tested are the primary criteria used for the selection of the most appropriate and cost-effective method for gold analysis. For gold explorers and miners, the diverse techniques for coarse gold analysis include Lead Collection Fire Assay, Screen Fire Assay or Accelerated Cyanide Leach as against Bulk Leach Extractable Gold (BLEG) used mainly for fine grained gold measurements. The quality of the assay data cannot be over-emphasised, since this information defines the grade of the resource that is used in the evaluation of a mineral resource estimation and its economic viability

Often at mine-site laboratories, Fire Assay or Lead Collection Fire Assay remains the method for quantitative gold determination by most companies who fail to critically examine the effectiveness of this method in relation to BLEG particularly so when it comes to leachability and reproducibility that could be due to the characteristics of the ore body.

This study is an attempt to establish difference in the gold content of group of samples using Bulk Leach Extractable Gold (BLEG) and the widely accepted Fire Assay method and furthermore to clearly define the cost difference between these two analytical techniques.

\section{Geological setting}

The Paleoproterozoic rocks known as the Birimian which were formed at 2.0-2.3 Ga. [1] is exposed in Ghana as north- and northeast-trending belts of metasedimentary and metavolcanic rocks which have been intruded by syn-tectonic and late tectonic suites of granitoids (Fig. 1). The metasedimentary rocks are primarily phyllites and greywackes but there are also weakly metamorphosed tuffs, feldspathic sandstones and Mn- and Si-rich chemical sediments.

The rock units of the metavolcanics are originally predominant tholeiitic basalts and pyroclastic rocks, some of which have been metamorphosed to hornblende-actinolite schist, calcareous-chlorite schist and amphibolites. There are also, mafics and porphyries. The Birimian rocks have been metamorphosed to the greenschist facies and contain albite, chlorite, epidote, sericite, quartz and carbonate minerals. However, amphibolite facies is also common. The sedimentary and volcanic rock sequences of the Birimian are said to have been formed contemporaneously as lateral facies equivalents and [2] suggested that the Birimian group was laid down as volcanic pyroclastic and sedimentary rocks.

\subsection{Ashanti greenstone belt}

On the basis of structural and lithological belts, [3] divided Ghana into gold belts, which also represent geographic regions that are underlain by rocks with significant gold mineralisation. The Ashanti greenstone belt which is one of the belts that is in southwest Ghana (Fig. 1) comprises of three stratigraphic groups as the Sefwi Group, 
the Kumasi Group and the Tarkwa Group [4], [5] [6] established that the Sefwi Group is made of multiple layers of metamorphosed basalt and volcano-sedimentary rock, dated as being older than $2162 \pm 6$ Ma. The Kumasi Group relates to mica-schists and metavolcanoclastic sedimentary rocks deposited in the Kumasi Basin and in the Akyem Basin after $2154 \pm 2 \mathrm{Ma}$. [7]. The Sefwi and the Kumasi groups of the Birimian Supergroup are unconformably overlain by the Tarkwa Group [8]. The Tarkwa Group was deposited based on re-interpretation of $\mathrm{U} / \mathrm{Pb}$ detrital zircon ages between $2107 \mathrm{Ma}$ and $2097 \mathrm{Ma}$. [9]. These three groups were intruded by tonalitic, granodioritic, granitic and leucogranitic plutons in two phases during the Eburnean Orogeny: an Eo-Eburnean phase (ca 2187-2158 Ma) and an Eburnean phase (ca. 2125- $1980 \mathrm{Ma}$ ). Work on the Ashanti Belt by [10] on both Obuasi and Bogoso mines identified five phases of deformation; D1 Bedding-parallel foliation and shear zones, D2 Major crustal shortening, gently plunging isoclinal folds, thrust faults, D3 Further minor shortening, gently plunging 50- to 200-m-scale folds, D4 Upright, east-striking, NE-plunging 100- to 2,000-m-scale folds, D5 North-striking sinistral strike-slip faults and local reactivation of D2 thrust faults. Gold mineralization is synchronous with D5 sinistral strike-slip faults. However, work by Perrouty et al. [11] has identified D6 as a subvertical crenulation cleavage and reverse faults associated with NE-SW shortening. intermediate volcanic flows which are interbedded with minor horizons of volcaniclastics, clastic sediments such as wackes and magnetite rich sedimentary layers, most likely banded iron formations. The volcano-sedimentary sequence which is characterized by multiple ankerite-quartz veins is also intruded by syn-volcanic mafic intrusives and felsic porphyries [12].

The gold mineralization is structurally controlled and is in disjointed tabular to ribbon-like bodies of narrow dolomite/ankeritetourmaline bearing quartz veins. Sulphide minerals (predominantly pyrite) occurs within and around the quartz veins [11], [12].

\section{Materials and analytical methods}

Sampling and sample preparation protocols have been designed to produce the highest possible quality data given the nature of the target mineralization. The sampling technique depended on the grade distribution and so when the grade was uniformly distributed taking small sample $\left(2 \mathrm{~m}^{3}\right)$ was found to be effective [13]. Sampling was done by taking mineralized intersection zone from each diamond drillhole. However, for the RC drillhole, samples were collected at every $1 \mathrm{~m}$. The samples were analysed by the Bulk Leach Extractable Gold (BLEG) method and Fire Assay on the tails.

\subsubsection{Local geology and mineralisation}

The Wassa property lies in the south-eastern portion of the Ashanti Greenstone Belt within a volcano-sedimentary assemblage. The lithologies of the Wassa assemblage are predominantly of mafic to

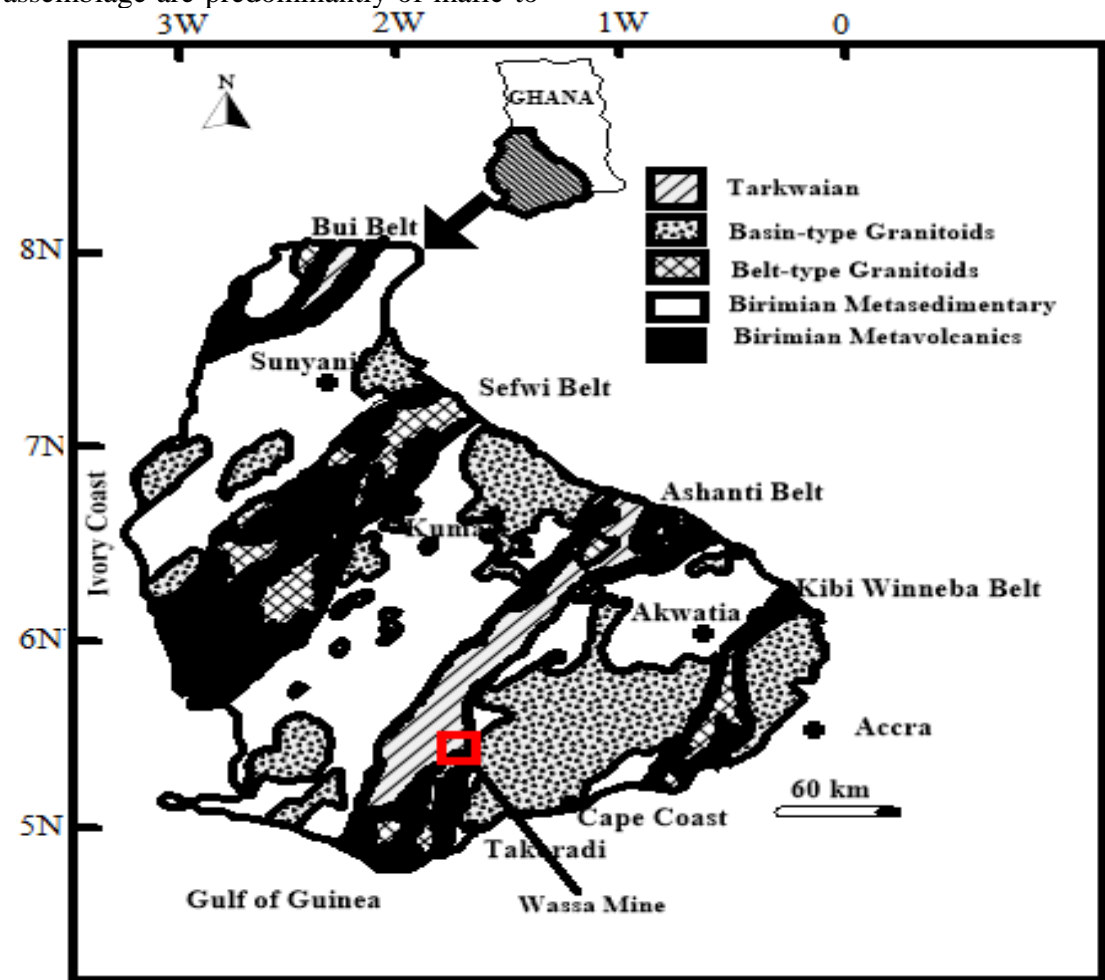

Fig. 1: Geological Map of Southwestern Ghana Showing the Location of the Wassa Mine.

A total of 779 samples made up of $54.2 \%$ drillhole samples and $45.8 \%$ quality control samples (cover standards, field duplicates and blanks) were analysed at the Tarkwa SGS laboratory, as well as the in-house laboratory on site. $1000 \mathrm{~cm}^{3}$ of $0.1 \%$ sodium cyanide concentration and lime $\left(30\right.$ grams of $\mathrm{Ca}(\mathrm{OH})_{2}$ were added to the sample after total pulverization. The mixture was allowed to be rolled for about 24 hours, after specified hour intervals. The data which was divided into control and drillhole samples categories was used to assess the competency of the BLEG method. The data was used for evaluation of Percentage Recovery analysis, Correlation of the data, Time Variation graphs, Half Absolute Relative Deviation and Cost Analysis.

\section{Results and discussions}

\subsection{Standard analysis}

Table 1: Summary of Certified Reference Materials (Standards)

\begin{tabular}{lllll}
\hline Standard & $\begin{array}{l}\text { Certified } \\
\text { mean }(\mathrm{Au} \\
\mathrm{g} / \mathrm{t})\end{array}$ & $\begin{array}{l}\text { Number of } \\
\text { Samples ana- } \\
\text { lyzed }\end{array}$ & $\begin{array}{l}\text { Lab. mean } \\
\text { values }(\mathrm{Au} \\
\mathrm{g} / \mathrm{t})\end{array}$ & $\begin{array}{l}\text { Lab. } \\
\text { bias } \\
(\%)\end{array}$ \\
\hline ST07/9453 & 0.21 & 62 & 0.212 & 1 \\
ST482 & 1.94 & 73 & 1.969 & 2 \\
ST48/8464 & 4.82 & 71 & 4.883 & 1 \\
\hline
\end{tabular}


Results from the Standards analysis (Table 1) indicate that SGS reports values were higher than expected with some variation to the detection limit. SGS returned assay of geostatistics standards with laboratory bias ranging between $1 \%$ and $2 \%$. Figure 2 gives clear explanation of how the certified material performed. For the purpose of resource evaluation, + or- 2 sd of the mean value is quite acceptable as checks on laboratories. The standards provide a good indication of the quality of sample management and contamination in the sample preparation process and is used as a criterion for accepting or rejecting batch job. The standards inserted into the various batches included high, medium and low grade ones. The data plotted was compiled at a period of time and the mean value of the standards was compared with the laboratory mean to find out how much bias and deviation was in the results. For a good standard, reporting within a period of time should be sinusoidal as is shown in Figure 2.

\subsection{Bulk leach extractable gold (BLEG) analysis}

Bulk Leach Extractable Gold (BLEG) technique is a partial extraction analysis in the sense that if some of the gold is retained in the samples which is the tails and we have to get a total recovery of the gold, then the tails must be subjected to Fire Assay in order to get the total gold. Due to the erratic nature of the Wassa mine deposits, bulk sampling has been recommended as the best way of sampling, hence the need for BLEG analytical method. Even though, the choice of sampling depends on the grade distribution, however in order not to underestimate or overestimate, bulk sampling was adopted as this would be expected to give more representative results. Though Fire Assay on the tails is significant, however statistical analysis shows that it may not be very necessary. The dissolved gold in cyanide solution obtained from 1 to 24 hours was used to prepare leachability graphs. This total gold content is then from the analytical methods of BLEG plus Fire Assay on the tails.

Any disparity between both analytical results (i.e. BLEG and Fire Assay) means that the Fire Assay is enhancing the total gold recovery but if there is a strong correlation between the two, then the BLEG is doing well and it may therefore may not be necessary to carry out the Fire Assay analysis on the tails.

Many statistical tools including Percentage recovery graph and Scatter plot as shown in figure 3 and figure 4 respectively were used to confirm effectiveness of the BLEG and a summary of few extracted grades with optimum recovery levels are captured in Table 2.

Table 2: Summary of Leachability of Wassa Samples

\begin{tabular}{|c|c|c|c|c|c|c|c|}
\hline $\begin{array}{l}\text { Pro- } \\
\text { spect }\end{array}$ & Sample ID & $\begin{array}{l}\text { Sample } \\
\text { Type }\end{array}$ & $\begin{array}{l}\text { Extracted } \\
\text { Grade }(g / t)\end{array}$ & $\begin{array}{l}\text { Residual } \\
\text { Grade(g/t) }\end{array}$ & $\begin{array}{l}\text { Total } \\
\text { Gold }\end{array}$ & $\begin{array}{l}\text { BLEG Recovery } \\
(\%)\end{array}$ & $\begin{array}{l}\text { Fire Assay Recov- } \\
\text { ery } \\
(\%)\end{array}$ \\
\hline \multirow{19}{*}{$\begin{array}{l}\text { Wassa } \\
\text { Deposit }\end{array}$} & $1204850 \mathrm{C}$ & $\mathrm{RC}$ & 15.6 & 0.06 & 15.66 & 100 & 0 \\
\hline & $1349266 \mathrm{~A}$ & $\mathrm{RC}$ & 14.3 & 0.61 & 14.91 & 96 & 4 \\
\hline & BSDD296377 & DD & 14.4 & 0.2 & 14.6 & 99 & 1 \\
\hline & BSDD205315 & DD & 14.5 & 0.34 & 14.84 & 98 & 2 \\
\hline & BSDD296371 & DD & 28.5 & 0.14 & 28.64 & 100 & 0 \\
\hline & SEDD079123 & DD & 18.4 & 0.26 & 18.66 & 99 & 1 \\
\hline & SEDD079130 & DD & 20.2 & 0.17 & 20.37 & 99 & 1 \\
\hline & SEDD068220 & DD & 51.2 & 1.06 & 52.26 & 98 & 2 \\
\hline & SEDD058095 & DD & 94.2 & 2.7 & 96.9 & 97 & 3 \\
\hline & STDD032 & $\mathrm{RC}$ & 10.4 & 0.17 & 10.57 & 98 & 2 \\
\hline & STDD032 & $\mathrm{RC}$ & 10.6 & 0.14 & 10.74 & 99 & 1 \\
\hline & STDD019 & DD & 11.5 & 0.36 & 11.86 & 97 & 3 \\
\hline & STDD033 & $\mathrm{RC}$ & 11.5 & 0.4 & 11.9 & 97 & 3 \\
\hline & STDD018 & $\mathrm{RC}$ & 12.2 & 0.44 & 12.64 & 97 & 3 \\
\hline & STDD027 & DD & 12.9 & 0.74 & 13.64 & 95 & 5 \\
\hline & $1330086 \mathrm{~A}$ & $\mathrm{RC}$ & 30.1 & 0.57 & 30.67 & 98 & 2 \\
\hline & 242DD054109 & DD & 30.5 & 2.38 & 32.88 & 93 & 7 \\
\hline & 242DD068108 & DD & 37.3 & 0.85 & 38.15 & 98 & 2 \\
\hline & 242DD068106 & DD & 122 & 0.99 & 122.99 & 99 & 1 \\
\hline
\end{tabular}

Au Values of ST $48 / 8462(4.82 \mathrm{~g} / \mathrm{t})$ Returned by $\mathrm{SGS}, \mathrm{N}=71$, Bias=1\% BLEG

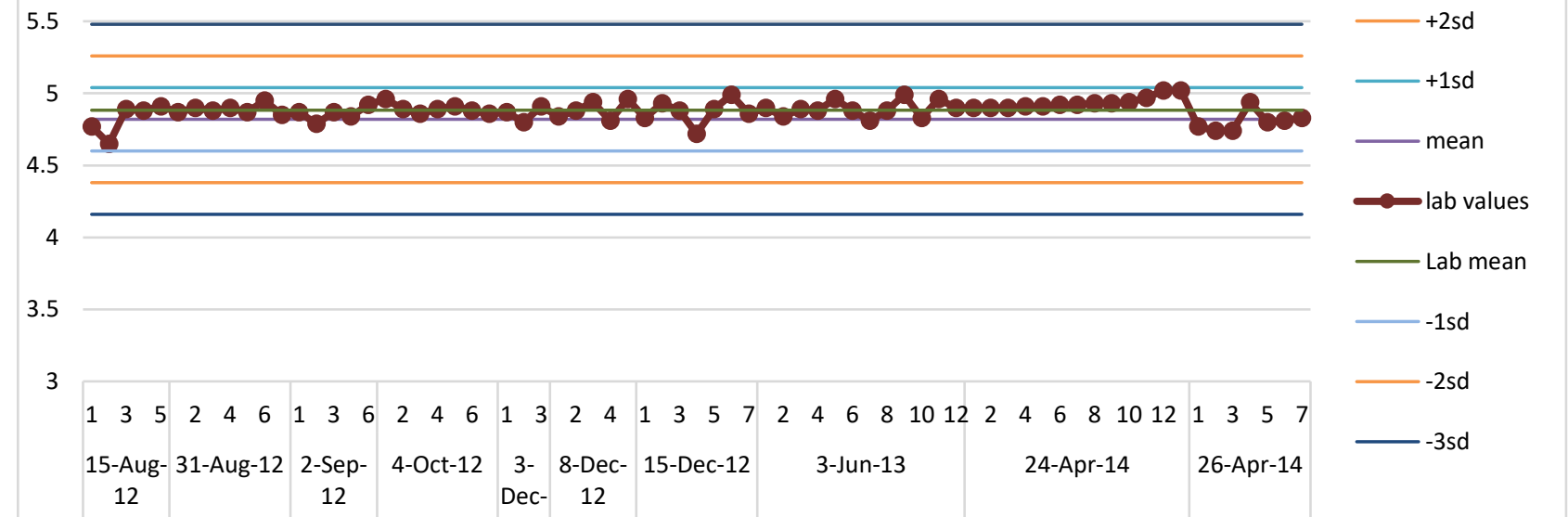

Fig. 2: A Plot of Au Values of ST 48/8462 (4.82 G/T) Returned by SGS. 


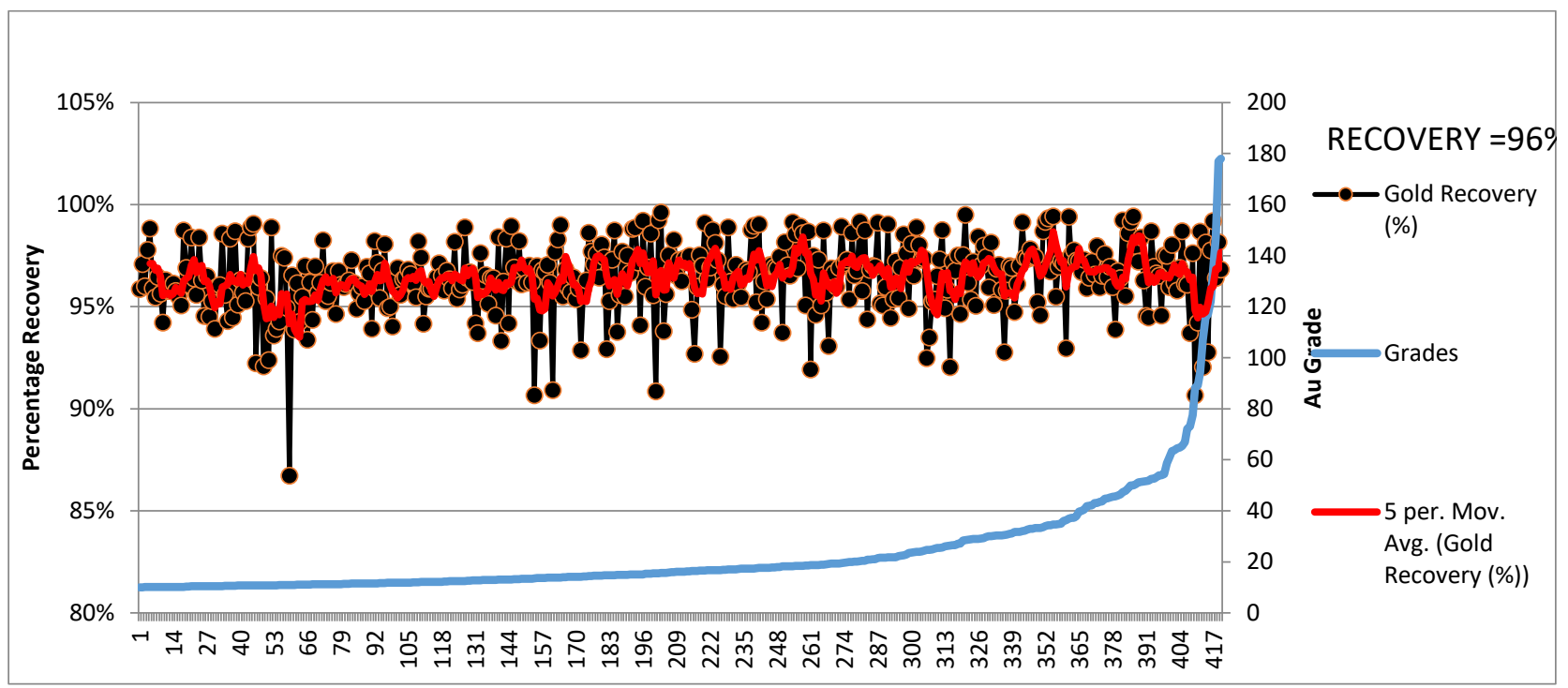

Fig. 3: A Plot of Percentage Recovery with Au Grade (Wassa Mine Deposit Samples).

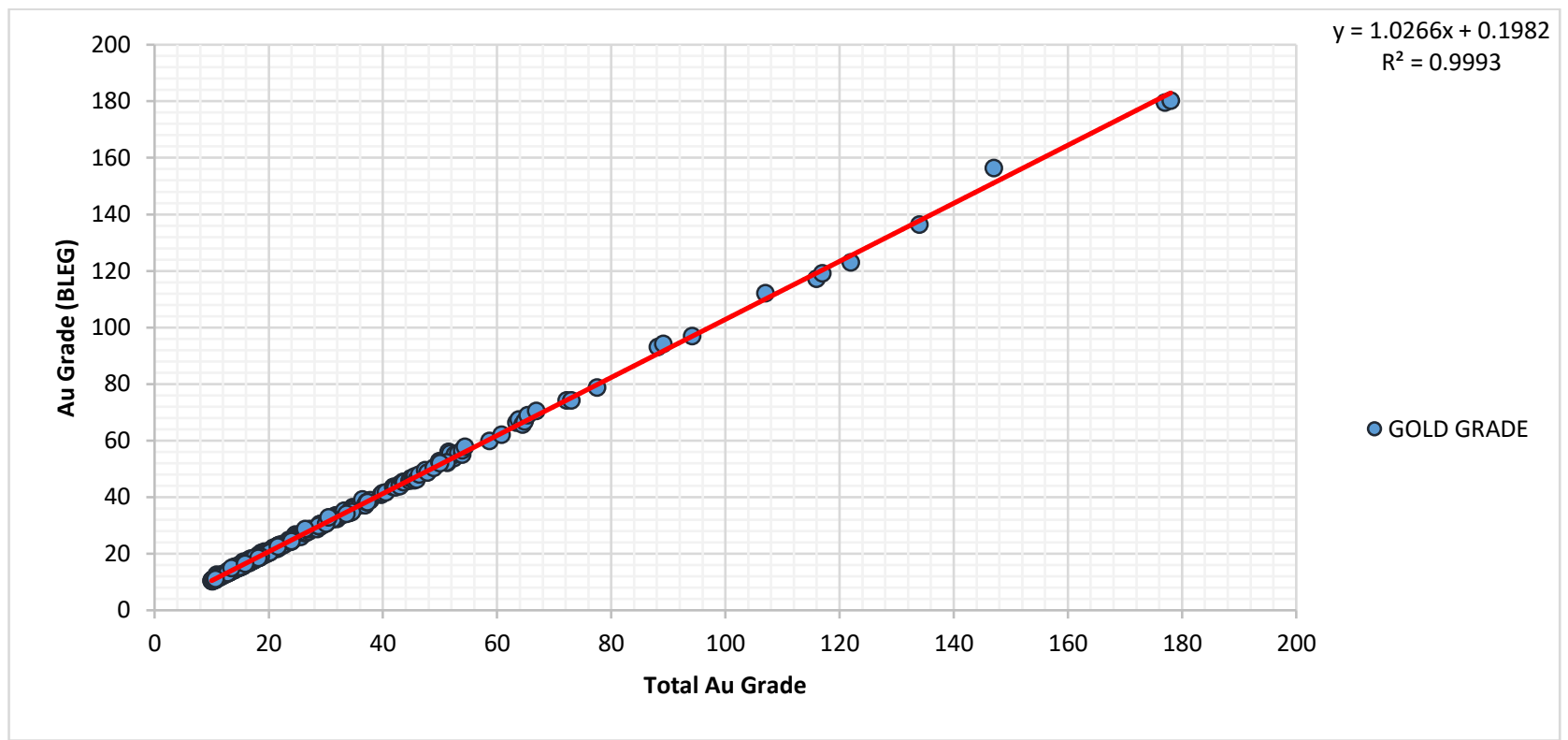

Fig. 4: Correlation Graph of Au Grade (BLEG) Vs. Total Au Grade (BLEG + FA).

\subsection{Cost analysis}

Two scenarios are discussed here in relation to the element of cost. One is related to the analytical method and the cost when the samples are not divided based on their gold grades and the other, the analytical method and the cost when the samples are divided based on their grades.

Cost price for samples analysed have been derived from the SGS quotes for 2014 for BLEG and Fire Assay methods. The unit cost for analysing sample by BLEG method is US\$ 11.45 and that for Fire Assay method is US\$10.35.

For a total of 6111 DD and RC samples from B-Shoot prospect of the mine that were sent to the laboratory, the analytical results showed that 377 samples had values $\geq 10 \mathrm{~g} / \mathrm{t}$ and 5734 samples were $\leq 10 \mathrm{~g} / \mathrm{t}$.

\subsubsection{Scenario one}

Assay Cost $=$ Number of samples $\times$ Cost. Where the cost would depend on the grade of the sample. Most exploration companies would opt for this cheap BLEG method for the analysis of the samples initially and obviously would have no idea about the grade of gold in each sample. So if we had decided not to categorise the samples into their grades and had to use the BLEG as a cheap analytical method, then the cost would be

Assay cost $=6111 \times$ US $\$ 11.45=$ US $\$ 69970.95$

\subsubsection{Scenario two}

Generally, at the Golden Star Resources Limited, Wassa Mine inhouse laboratory,

Assay Cost $=$ Number of samples $\times($ Cost of BLEG + Cost of Fire Assay on tails)

However, the cost of this analytical procedure would also depend upon the Au grade.

Ore Samples with Au Grades $\geq 10 \mathrm{~g} / \mathrm{t}$

This analytical procedure would involve Fire assay on the tails as well. Therefore,

Assay Cost $=377 \times$ US $\$(11.45+10.35)=\mathrm{US} \$ 8,218.6$

ORE SAMPLES WITH Au GRADES $<10 \mathrm{~g} / \mathrm{t}$

Here, analysis is by BLEG method alone, hence 
Cost of BLEG Method =5734 samples $\times$ US\$11.45 $=$ US $\$ 65,654.3$

And this gives the Total Assay cost $=$ US $\$ 65,654.3+$ US $\$ 8,218.6$ $=$ US $\$ 73,872.9$

If a comparative analytical cost of the two scenarios are done on the ore samples, then using the BLEG method alone,

$$
\text { Assay Cost }=6111 \times \text { US\$ } 11.45=\mathrm{US} \$ 69,970.95 \text {. }
$$

However, this amount of US\$ $69,970.95$ is less than the Assay cost of US\$ 73,872.9.

Therefore, the analysis on the 6111 samples by conducting Fire Assay method on the tails as well can be avoided in favour of the BLEG method alone which can be done by totally pulverizing the samples. This makes this BLEG method possible and cheaper, hence more cost effective.

\section{Conclusions}

The comparative study of bulk leach extractable gold (BLEG) and fire assay methods on the Wassa deposit at Golden Star Wassa Mine Limited has provided meaningful insight on which following conclusions can be made:

- The BLEG method analysis which gave a minimum recovery of $96 \%$ shows that there might not be the need for Fire Assay on the tails as it does not have much impact on the total gold recovery.

- The various statistical tools also proved that the Bulk Leach Extractable Gold (BLEG) method has a good optimum leached point.

- The BLEG method analysis on the Wassa Mine Deposit samples shows that the samples are leachable.

- BLEG method is not cost effective when there are suspicious higher gold grades.

\section{Acknowledgement}

We would like to express our sincere gratefulness to the Management of Golden Star Resources Limited, Wassa Mine for the use of the data in this study which is the M.Sc project by the first author.

\section{References}

[1] Taylor, N.P., Moorbath, S., Leube, A., Hirdes,W. Early Proterozoic crustal evolution in the Birimian of Ghana: constraints from geochronology and isotope geochemistry. Precambrian Res. 56, (1992) 97111. https://doi.org/10.1016/0301-9268(92)90086-4.

[2] Leube, A., Hirdes, W., Mauer, R., Kesse, G.O. The early Proterozoic Birimian Supergroup of Ghana and some aspects of its associated gold mineralization. Precambrian Research, (1990) 46-165. https://doi.org/10.1016/0301-9268(90)90070-7.

[3] Mensah, M.K., Iddirisu, Y., Gaisie, J.S., Manu, J., and Attoh, K. The gold belts of unpubl. (1988). Report prepared for the Government of Ghana and United Nations. Project GHA/86/005 technical assistance to the Minerals Commission, Accra, Ghana.

[4] Adadey, K., Clarke, B., Théveniaut, H., Urien, P., Delor, C., Roig, J.Y., Feybesse, J.L., (2009). Geological map explanation - Map sheet 0503 B (1:100 000), CGS/BRGM/ Geoman, Geological Survey Department of Ghana (GSD). No MSSP/2005/GSD/ 5a.

[5] Perrouty, S., Lindsay, M.D., Jessell, M.W., Aillères, L., Martin, R., Bourassa, Y. 3D modeling of the Ashanti Belt, southwest Ghana: evidence for a lithostratigraphic control on gold occurrences within the Birimian Sefwi Group. Ore Geol. Rev. 63, (2014) 252-264. https://doi.org/10.1016/j.oregeorev.2014.05.011.

[6] Loh, G., Hirdes,W. Explanatory notes for the geological map of southwest Ghana 1:100,000: sheets Sekondi (0402A) and Axim (0403B): Ghana. Geol. Surv. Bull. 49, (1999) 149.

[7] Oberthür, T., Vetter, U., Davis, D.W., and Amanor, J.A. Age constraints on gold mineralization and Paleoproterozoic crustal evolution in the Ashanti belt of southern Ghana: Precambrian Research, v.
89, (1998) p. 129-143. https://doi.org/10.1016/S03019268(97)00075-2.

[8] Pigois, J.P., Groves, D.I., Fletcher, I.R., McNaughton, N.J., Snee, L.W. Age constraints on Tarkwaian palaeoplacer and lode-gold formation in the Tarkwa-Damang district, SW Ghana. Miner. Deposita 38, (2003) 695-714. https://doi.org/10.1007/s00126-003-0360-5.

[9] Allibone A., Teasdale J., Cameron G., Etheridge M., Uttley P., Soboh A., Appiah-Kubi J., Adanu A., Arthur R., Mamphey J., Odoom B., Zuta J., Tsikata A., Pataye F., Famiyeh S., Lamb E. Timing and Structural Controls on Gold Mineralization at the Bogoso Gold Mine, Ghana, West Africa; Economic Geology, Vol. 97, (2002b) pp. 949-969. https://doi.org/10.2113/gsecongeo.97.5.949.

[10] Perrouty, S., Lindsay, M.D., Jessell, M.W., Aillères, L., Martin, R., Bourassa, Y. 3D modeling of the Ashanti Belt, southwest Ghana: evidence for a lithostratigraphic control on gold occurrences within the Birimian Sefwi Group. Ore Geol. Rev. 63, (2014) 252-264. https://doi.org/10.1016/j.oregeorev.2014.05.011.

[11] Bourassa Y.; 2003. Geology of the Wassa Mine Report; Golden Star Resources Ltd, (2003) 32p unpublished.

[12] Perrouty S., Jessell M.W., Aillères L., Apau D., Velasquez G., Siebenaller L., Miller J., Bourassa Y., Beziat d., Baratoux L. Tectonic Context of Eoeburnean Gold Mineralization in Wassa mine, Southwest Ghana, (2012) 50p unpublished.

[13] Pitard, F.F. Pierre Gy's sampling theory and sampling practice, 2nd edition, CRC Press, New York, (1993) 488p. 